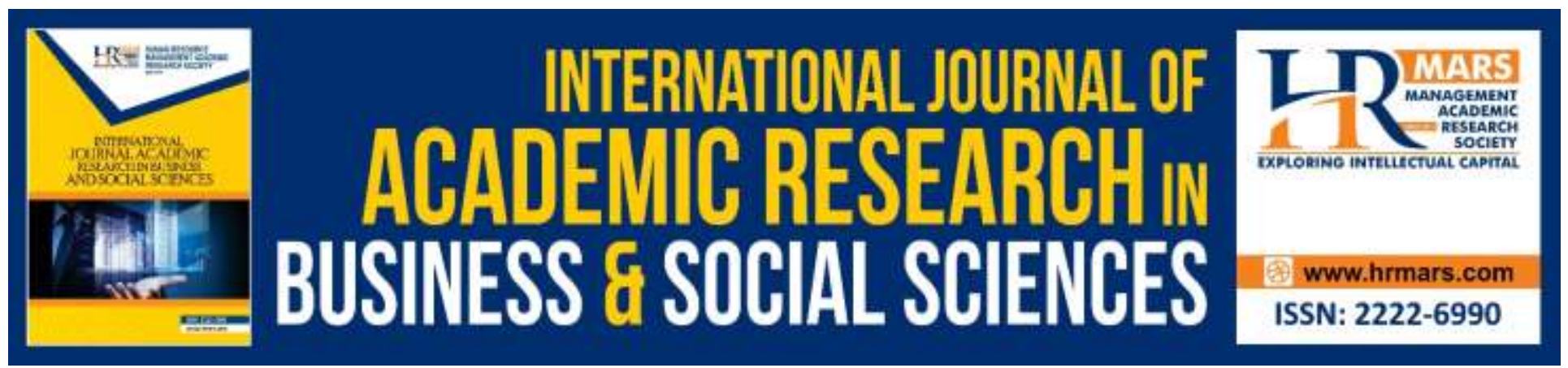

\title{
Students' perceptions on Cooperative Problem-Based Learning (CPBL) in the language Classroom
}

\author{
Haslinda Binti Othman, Hairuzila Binti Idrus
}

To Link this Article: http://dx.doi.org/10.6007/IJARBSS/v9-i13/6476

DOI:10.6007/IJARBSS/v9-i13/6476

Received: 02 August 2019, Revised: 27 August 2019, Accepted: 02 September 2019

Published Online: 23 September 2019

In-Text Citation: (Othman \& Idrus, 2019)

To Cite this Article: Othman, H. B., \& Idrus, H. B. (2019). Students' perceptions on Cooperative Problem-Based Learning (CPBL) in the language Classroom. International Journal of Academic Research in Business and Social Sciences, 9(13), 291-303.

\section{Copyright: (c) 2019 The Author(s)}

Published by Human Resource Management Academic Research Society (www.hrmars.com)

This article is published under the Creative Commons Attribution (CC BY 4.0) license. Anyone may reproduce, distribute, translate and create derivative works of this article (for both commercial and non-commercial purposes), subject to full attribution to the original publication and authors. The full terms of this license may be seen

at: http://creativecommons.org/licences/by/4.0/legalcode

Special Issue: Revolutionizing Education: Challenges, Innovation, Collaboration, 2019, Pg. 291 - 303

Full Terms \& Conditions of access and use can be found at http://hrmars.com/index.php/pages/detail/publication-ethics 


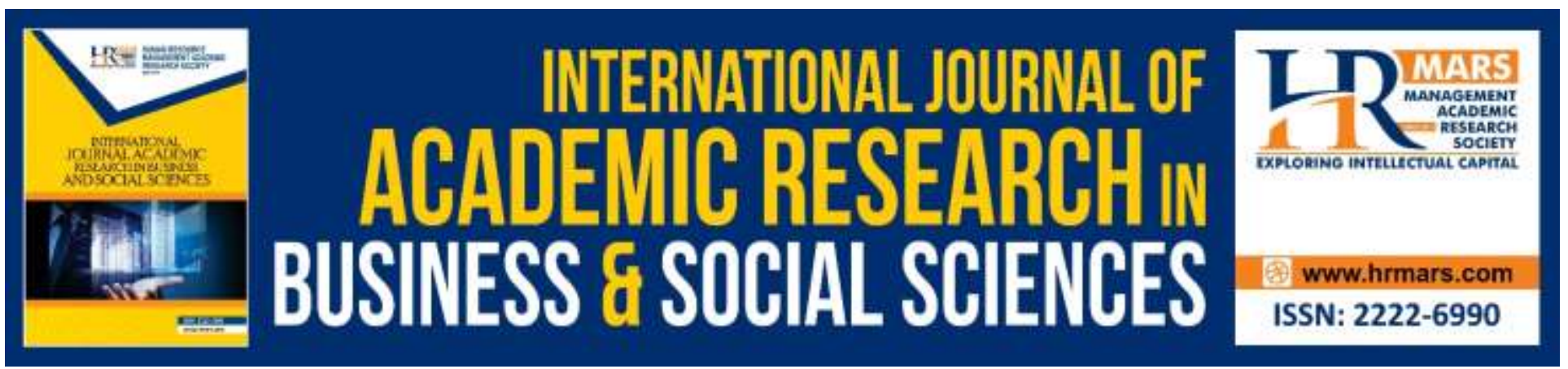

\title{
Students' Perceptions on Cooperative Problem-Based Learning (CPBL) in the Language Classroom
}

\author{
Haslinda Binti Othman, Hairuzila Binti Idrus \\ Department of Management and Humanities, Universiti Teknologi Petronas \\ 32610 Seri Iskandar, Perak Darul Ridzuan, Malaysia \\ Email: haslinda_g03507@utp.edu.my, hairuzi@utp.edu.my
}

\begin{abstract}
$21^{\text {st }}$ century poses greater challenges for graduates to secure positions in the employment sector. To prepare the graduates for the challenges, the teaching and learning approach needs to be transformed for better outcomes. Cooperative problem-based learning ( $C P B L)$ is a new approach that consists the elements of problem-based learning and cooperative learning. Its advantages is numerous that it could help to improve critical thinking skills, creativity, problem solving skills, social skill, leadership skills and motivation, which leads to better experience in the learning process. CPBL has been found to be used in the content-based class such as engineering and has displayed positive results. The elements of critical thinking and the usage of skills in the CPBL module have proposed that it is a suitable approach for the language classroom. A survey using questionnaires on students' perceptions, motivation and strategies for learning has been conducted on undergraduate students to have insights of CPBL outcome in the language classroom. The questionnaire is later analyzed using exploratory factor analysis in the SPSS software. The results show that the most loaded factor is selfefficacy for learning, followed by extrinsic goal orientation, and intrinsic goal orientation. All these factors correlate with one another that the students focus on their extrinsic goals more than their intrinsic goals to increase their self-efficacy.
\end{abstract}

Keywords: CPBL, MSLQ, Students' Perceptions, Teaching Pedagogy, Writing Classroom

\section{Introduction}

The education sector is experiencing a paradigm shift and is moving fast in accordance with the growing technology and economy to fulfill the job market demand. Murugesan (2003) states that, apart from science and technology, English language is also given importance as it is now widely used in all aspects of life. English language is a global lingua franca and is a vehicle to gain information in science and technology. The mastery in English language could help a person to have advantage either in school or in his career. Those who are able to use good English language are often preferred 
by employers to represent them. Educational institutions have a big role to play in preparing the students with the type of skills needed and equip them for jobs and technologies that do not yet exist in order to solve unknown problems (Dass, 2014). Educators too are facing challenges in educating the students to master English language, meet new skills, and narrow the achievement gap.

Considering the fact that many learners have not realized of the importance of mastering the language skills, it has affected them to the extent that they are unable to get a job after completing their studies. Employers often mention deficiencies in English and written communication among graduates and urge them to be equipped academically (ACTE, 2018). Moreover, employability skills such as oral and written communication, problem solving, critical thinking, adaptability, responsibility and teamwork are the most critical for employers in selecting the best candidate. Lamentably, these skills are not emphasized in traditional academic classrooms. Traditional learning in the skill-based classroom needs transformation and alternative approaches are required to retain students' attention span, to enhance students' learning capacity and to encourage active participation in class. Memorization of facts and procedures are not enough in the global economy society, but understanding of complex concepts, ability to work with the concepts creatively to generate new ideas, new theories, new products and new knowledge will help the learners to succeed later in life (ET, 2018). The generation $Z$ has to be able to think critically, evaluate their readings, express themselves clearly, both written and oral, understand scientific and mathematical thinking, integrate and use knowledge as well as take responsibility for their own continuing and life-long learning.

Since higher education is closely related to the employment sector, the learners need to be prepared of the upcoming challenges. The language educators could play a role in helping the students to enhance their academic skills. Effective teaching practices such as promoting active learning, applying different teaching strategies and giving prompt feedback could help in contributing to the skills development of the students and these skills are best developed when they are integrated across the curriculum (Kwok, 2003). According to Scarino and Liddicoat (2009), language classroom is the best platform to teach learners in utilizing their academic skills as it relates to the intra and interpersonal skills.

This paper specifically looks inside the writing classroom. Learning writing is considered crucial to increase one's career prospective. Writing skills are not only used in the classroom to compose essays, but also for writing important documents at work. It is one of the difficult skills to learn as it involves the cognitive domain. It does not only involve the writing conventions, but also include learning comprehension, application and synthesis of new knowledge (Defazio, Jones, Tennant \& Hook, 2012). Regardless, many learners fail to see the benefits of writing that they take it for granted. They see writing as a course to be completed, and most learn to get good grades only. Due to this, many learners are unable to present effective communication and ideas in a written communication, which is seen as important once they graduate.

One of the ways to be in line with the current mission of the Ministry of Higher Education; active participation in class and education should sustain high quality educational ecosystems to develop individual's potential to meet the country's aspiration is by refining the teaching approaches. Cooperative Problem-based Learning (CPBL) is a recent method that puts the combination of two popular teaching methods; cooperative learning and problem-based learning (PBL) could create a better teaching and learning outcomes. The existence of CPBL is due to challenges of the world that lead to wide spread interest in producing high quality graduates (Yusof, Hassan, Jamaludin \& Harun, 
2012). By implementing only cooperative learning or PBL is not enough to train the young people for the future uptakes. CPBL allows students to take control of their own study and at the same time hones their critical thinking and problem solving skills. It uses the five principles of cooperative learning as well as the essential elements of PBL. Educators in mostly engineering subjects have used CPBL to train students using their thinking skills as well as social skills. In classes where CPBL was used, students were able to improve their interpersonal skills and master the knowledge learnt because CPBL promotes deep involvement throughout the learning process (Adi, Phang \& Yusof, 2012). Students were also seen to have clearer understanding of evaluating other's work in order to progress and developed skills in working the assessment (Suharta \& Lynna, 2013). Consequently, the students are able to improve their learning motivation, attitude towards learning, in addition to improving soft skills and teamwork (Yusof, Hassan, Jamaludin \& Harun, 2011a).

Since CPBL revolves around skills; critical thinking, problem solving and social skills, it is quite useful in the skill-based classroom like language. When CPBL is used, the learners will need to use their language skills; speaking, listening, writing and reading to communicate and search for information. The learners will also able to enhance their critical thinking, problem solving and social skills when brainstorming for the problem solutions. The practical activities in the language learning are in agreement with the CPBL approach. In particular, CPBL in writing class brings advantages to learners as it helps to create meaningful activities. According to Azman and Ling (2012), when learners work on solving the problems, their activities tend to trigger motivation and engagement since it requires learners to search for materials and constantly relate the information they have with their action. This by some means enables them to integrate content knowledge with their English knowledge (Azman \& Ling), like writing. The PBL elements help learners to gain more information, have deeper understanding and better retention of knowledge. It appears to be an effective strategy to train competent and skilled learners as well as promoting long-term memory retention and skills while learning (Yew \& Goh, 2016).

Moreover, the suitability of CPBL in the writing class is because the PBL elements can serve as a useful context in helping learners to develop their critical thinking, which is relevant to writing (Kumar \& Rafaei, 2017). In view of the fact that writing is closely related to critical thinking, PBL is an ideal approach to practice and develop critical thinking and problem solving as the learners learn the domain-specific knowledge. Battaglia (2017) explains that the process of writing involves critical thinking where students are required to do a purposeful and reflective analysis to reach conclusions. Learning with PBL is perceived as an integrated approach to teach critical thinking and problem solving skills and seems to be appropriate to be used in the writing class (Kek \& Huijser, 2011; Kumar \& Rafaei). In addition, the learning principles of cooperative learning will assist learners in developing and managing group dynamics. Learners will work and learn together actively in small groups to accomplish a common goal in a mutually helpful manner (Davidson \& Major, 2014).

Thus, the combination of cooperative learning and PBL in CPBL creates a relevant approach for the skill-based classroom like writing. It is a great way to complement the traditional teaching as it helps the learners to be more motivated, confident, creative with problems and understand the importance of group work (Suharta \& Luthan, 2013). Writing does not only involve the cognitive part, but also the practical activities such as communication, finding information, brainstorming and organizing ideas, which are analogous with the CPBL method. 
Since CPBL has never been used in the language components, this paper will look at students' perceptions towards the implementation of CPBL in the writing classroom and possibly could give insights upon its execution.

\section{Method and Methodology}

This study employed a quantitative approach using a correlational design, where it focuses on gaining insights towards the students' perception, motivation and strategies for learning so that understanding towards the implementation of CPBL in the language classroom can be further explained. Correlational design is used to explore the relationship between two or more variables (Parmjit, Puzziawati \& Teoh, 2009). The students' foundation results were taken and a 20 items questionnaire on students' perception, motivation and learning strategies adapted by Pintrich and De Groot (1990) was used to study the relationship between students' performance and the effectiveness of CPBL in the language classroom. In support of this view, Privitera (2013) mentions that surveys or questionnaire are often used with correlational research design to determine the extent to which the values for the factors are related or change in an identifiable pattern. The questionnaire is using 5 point Likert scale with number one being strongly agreed and number five being strongly disagree.

This questionnaire was given to the students to lay the foundations of CPBL implementation and its success in the language classroom. By understanding the students' perception, motivation, and learning strategy, it may provide comprehension of the research outcomes. The data of the questionnaire is later analyzed using SPSS and is using exploratory factor analysis to explain the results. Exploratory factor analysis is used to see the number of factors and the rotation of axes to help in data interpretation (Parmjit, Puzziawati \& Teoh, 2009)

\section{Participants and Data Collection}

Approximately 60 undergraduate students who were taking Academic Writing class were selected. They were informed of their participation in the study and were given the MSLQ questionnaire to identify their perceptions, motivation and strategies in learning at the beginning of the semester. These students are enrolled in various engineering and technology courses ranging from civil, mechanical, electrical, petroleum, petroleum and gas, chemical, information technology as well as business information system. According to Chaudhary and Israel (2017), there is no prescribed sample size for a field test despite suggestions from several researchers such as Sheatsley (1983) who recommends 10 to 25 respondents and Sudman (1983) who proposes 20 to 50 respondents as it depends on time and budget to carry the research. Since this is an initial study towards the implementation of CPBL in the writing class, 60 participants will be enough to yield the required information.

\section{Results}

The students' English foundation result was recorded as below. The frequencies of students receiving grade $\mathrm{A}$ and $\mathrm{A}$ - are high for both semesters compared to those who received grade $\mathrm{B}+, \mathrm{B}$ and $C$. However, there are 10 data missing from the questionnaire where the respondents did not fill them. 
INTERNATIONAL JOURNAL OF ACADEMIC RESEARCH IN BUSINESS AND SOCIAL SCIENCES

Vol. 9, No. 13, Special Issue: Revolutionizing Education: Challenges, Innovation, Collaboration, 2019, E-ISSN: 2222-6990 @ 2019 HRMARS

Table 1 Students' foundation results for semester 1

\section{Foundation Result Semester 1}

\begin{tabular}{|ll|l|l|l|l|}
\hline & & & & Valid & Cumulative \\
& & Frequency & Percent & Percent & Percent \\
\hline Valid & A & 10 & 15.9 & 18.9 & 18.9 \\
& A- & 26 & 41.3 & 49.1 & 67.9 \\
& B+ & 5 & 7.9 & 9.4 & 77.4 \\
& B & 12 & 19.0 & 22.6 & 100.0 \\
& Total & 53 & 84.1 & 100.0 & \\
Missing & System & 10 & 15.9 & & \\
Total & & 63 & 100.0 & & \\
\hline
\end{tabular}

Table 2 Students' foundation results for semester 2

\section{Foundation Result Semester 2}

\begin{tabular}{|ll|l|l|l|l|}
\hline & & & & Valid & Cumulative \\
& & Frequency & Percent & Percent & Percent \\
\hline Valid & A & 14 & 22.2 & 26.4 & 26.4 \\
& A- & 22 & 34.9 & 41.5 & 67.9 \\
& B+ & 4 & 6.3 & 7.5 & 75.5 \\
& B & 12 & 19.0 & 22.6 & 98.1 \\
& C & 1 & 1.6 & 1.9 & 100.0 \\
Missing & Total & 53 & 84.1 & 100.0 & \\
Total & System & 10 & 15.9 & & \\
\hline
\end{tabular}

Next, the first step of data analysis is to determine the number of factors to be extracted. The eigenvalues are listed for component 1 through 20. The eigenvalue greater than one rule suggested that 4 factors recorded eigenvalues of more than one $(9.095,2.064,1.513,1.203)$ and they account for $69.378 \%$ of the total variability. Therefore, they were extracted.

The four-factor solution is further confirmed by looking at the scree plot shown in figure 1, where the scree plot indicates four factors should be retained since the elbow occurs at eigenvalue number 4. 


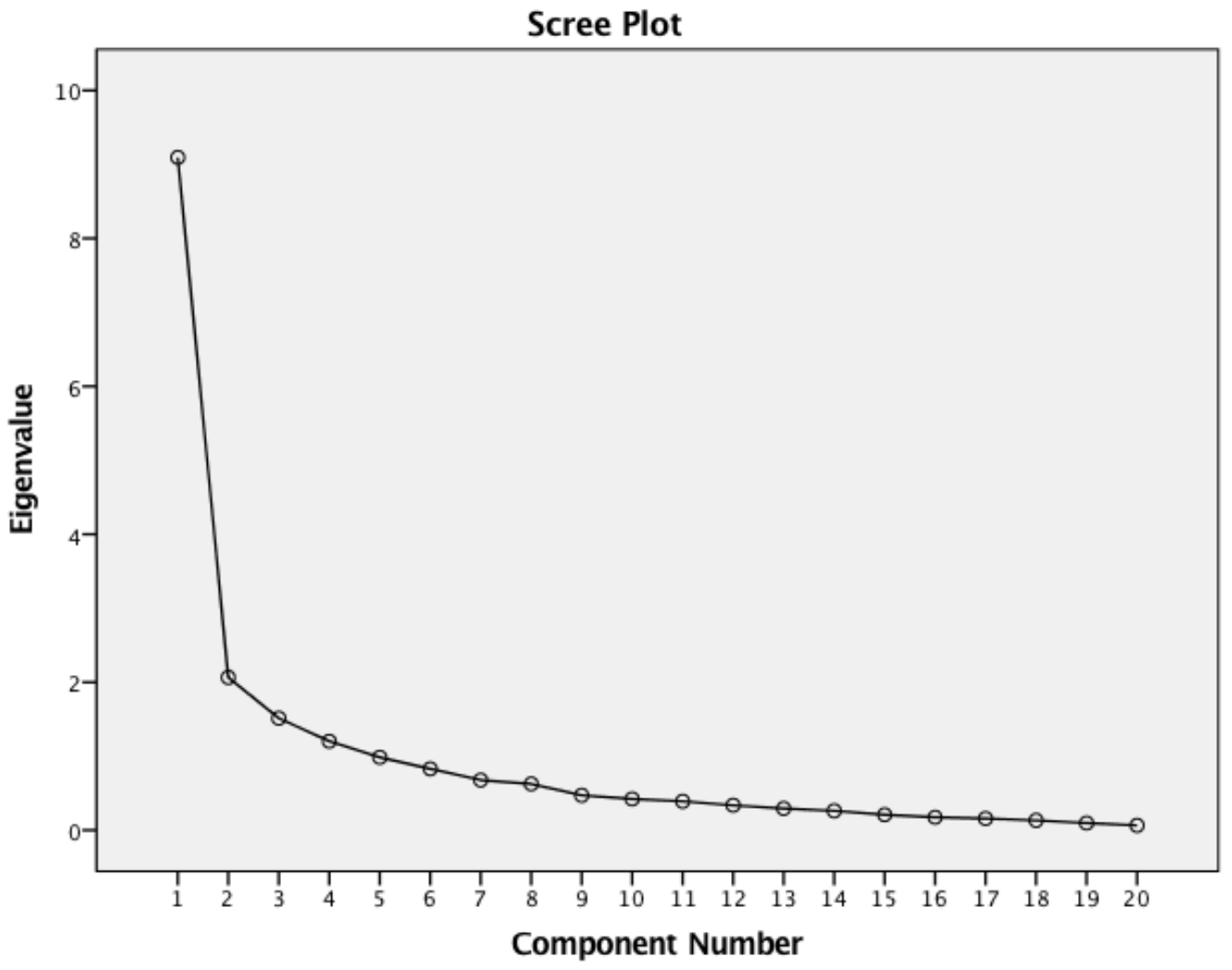

Fig 1 Scree plot of the eigenvalues

The result of the estimated factor loadings does not provide a clear grouping of variables to form a factor as almost all variables are loaded greatly on the first factor. Thus, the four-factor solution is rotated using Varimax with Kaiser Normalization Method to have a better interpretation of the factors.

According to Tabachnick and Fidell (2007), only items or variables with loadings of more than 0.32 are interpreted. The variable is more of pure measure of the factor when the loading is greater (Nausheen, 2016). Hence, 0.32 was used as a minimum-loading criterion of an item and they are grouped according to the highest factor loadings.

The new extracted factors were found to have a slight difference from the original MSLQ components. Factor one and factor two obtained high loadings with seven and eight variables while factor three and four gained three and two variables respectively. Due to the slight difference, each factor is labeled with different names. It appeared that only one item from task value is included with the self-efficacy for learning and performance. The analysis is perhaps due to the wording in the item that shows close similarity (Nausheen, 2016) with the other items of self-efficacy for learning performance and it talks about the self-confidence in going through the module. It seemed that the respondents associated the self-efficacy with task value. Thus, factor one is labeled as self-efficacy for learning.

Factor two gained the highest loadings with eight variables. Three items measured the extrinsic goal orientation, two items measured task value, two items measured control of learning 
beliefs and one measured intrinsic goal orientation. The items on factor two are not biased by any constructs and focus on benefits and achievement, which is quite similar with the MSLQ scale of extrinsic goal orientation. Due to this it was labeled as extrinsic goal orientation.

The third factor consisted three items of the intrinsic goal orientation. This factor is the same as the intrinsic goal orientation item on the original MSLQ scale, indicating that the intrinsic goal orientation operated effectively with the respondents. The third factor is therefore remains with the label of intrinsic goal orientation.

Factor four is loaded with one item from intrinsic goal orientation and one item from control of learning beliefs. The two items have almost the same content that talks about the beliefs in learning achievement. However, factor four is considered weak and was not meaningful as it consists only two items. It failed to show salient loading, hence was removed from the analysis, yielding a final three-factor solution. Costello and Osborne (2005) state that loading items should be investigated for their conceptual clarity particularly when they are cross load above .3 on more than once factor. The items need to be decided whether to include or omit in the final scale.

\section{Discussions}

The results of the study intend to look at the students' perception, motivation and learning strategy before they go through the CPBL model. The factor analysis results implied that the constructs of self-efficacy for learning are found to be the most meaningful for the respondents. This is most probably because the students have positive perceptions towards the subject and learning method as most of them have good English background based on the frequencies of $A$ and $A$ - that they received from their foundation studies. A study by Wang, Chang and Lai (2012) states that when people tend to value success and self-improvement, it is easier for them to think positively and expect success. Moreover, the grade they received before could be the motivating factor for their positive perceptions towards the learning method. Students need motivation to help them in learning and establish the right goal to enhance their learning (Long, Ming \& Chen, 2013). 
Table 3 Loading items in factor one

\section{Rotated Component Matrix ${ }^{a}$}

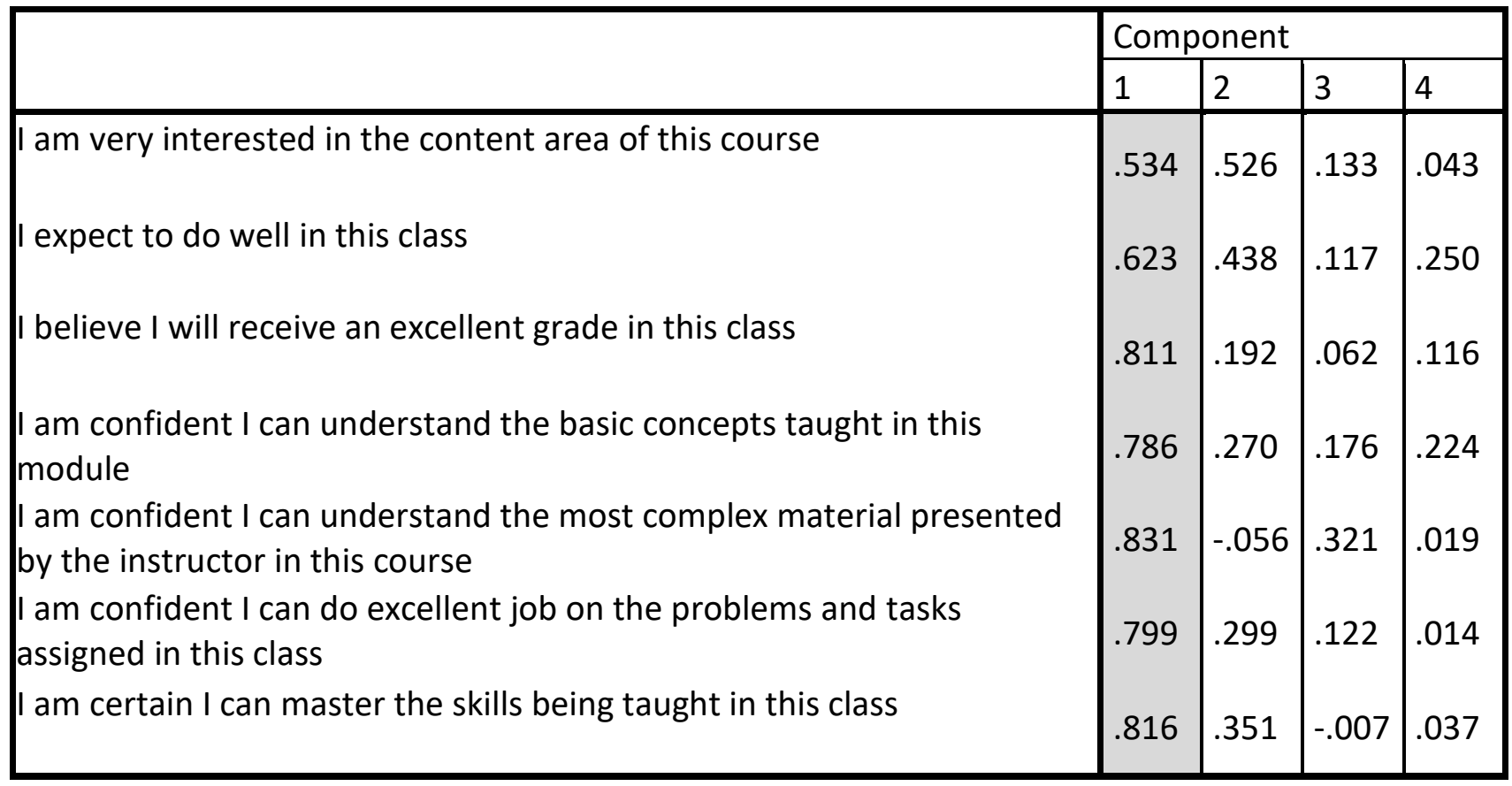

The second factor is more on extrinsic goal orientation where the students are more concern on getting the rewards. Extrinsic goal, by definition focuses on obtaining rewards and positive evaluations from others (Schmuk, Kasser \& Ryan, 2000) and such goals often reflect a sense of insecurity, which could lead to more stress, ego and controlled behavior if they do not satisfy one's need (Kasser, Ryan, Zax \& Sameroff, 1995; Sheldon \& Kasser, 1995; Kasser \& Ryan, 1996 in Schmuk, Kasser \& Ryan, 2000). Consequently, it suggests that students have positive attitude towards the CPBL method because they are concerned of their grades and what others think of their performance. Items 'getting a really good grade is the most important thing for me right now' and 'I want to do well in this module because it is important to show my ability to my family, friends, employer or others' strongly indicates that the students have a sense of insecurity towards others' thoughts. Therefore, they put high loading on the second factor. 
Table 4 Loading items in factor two

Rotated Component Matrix ${ }^{a}$

\begin{tabular}{|c|c|c|c|c|}
\hline & \multicolumn{4}{|c|}{ Component } \\
\hline & 1 & 2 & 3 & 4 \\
\hline It is important for me to learn the module material in this class & .519 & .622 & -.002 & .040 \\
\hline $\begin{array}{l}\text { Understanding the subject matter in this module is very important to } \\
\text { me }\end{array}$ & .408 & .610 & .172 & .378 \\
\hline $\begin{array}{l}\text { Getting a really good grade is the most important thing for me right } \\
\text { now }\end{array}$ & .388 & .470 & .176 & .347 \\
\hline I think the teaching material in this module is useful for me to learn & .339 & .744 & .204 & .213 \\
\hline $\begin{array}{l}\text { I want to do well in this module because it is important to show my } \\
\text { ability to my family, friends, employer or others }\end{array}$ & .263 & .627 & -.085 & -.252 \\
\hline $\begin{array}{l}\text { What I learn now will enable me to do something more interesting } \\
\text { once I've finished the module } \\
\text { It is my own fault if I don't learn the material in this course }\end{array}$ & .429 & .493 & .312 & .208 \\
\hline $\begin{array}{l}\text { If I don't understand the module material, it is because I didn't try hard } \\
\text { enough }\end{array}$ & .121 & .725 & .342 & -.056 \\
\hline
\end{tabular}

Lastly, is the third factor that loads on the intrinsic goal orientation. In contrast to extrinsic goal, intrinsic goal is more on self-satisfaction; things that are essentially satisfying to the psychological needs such as autonomy, relatedness, competence and growth (Schmuk, Kasser \& Ryan, 2000). The students seem to focus more on extrinsic goal such as getting on good grades in their study instead of learning for knowledge. Relating to factor two, this could be the reason why they have positive perceptions and motivations towards the CPBL approach as what matters in learning are grade and people's perceptions. Innate learning for self-satisfaction and knowledge has become secondary. It is undeniable that receiving a good grade has a significant motivational on students, yet in recent years, many have denied the effectiveness of good grades in motivating students to learn (Stan, 2012). The teaching method needs to be improved and this current motivating factor for learning could somehow be different after they go through the CPBL method. 
Table 5 Loading Items in Factor Three

Rotated Component Matrix ${ }^{\mathrm{a}}$

\begin{tabular}{|c|c|c|c|c|}
\hline & \multicolumn{4}{|c|}{ Component } \\
\hline & 1 & 2 & 3 & 4 \\
\hline $\begin{array}{l}\text { prefer course materials that really challenges me so I can learn new } \\
\text { things }\end{array}$ & .242 & .042 & .878 & -.072 \\
\hline $\begin{array}{l}\text { l prefer course material that arouses my curiosity, even if it is difficult to } \\
\text { learn }\end{array}$ & .099 & .248 & .853 & .055 \\
\hline $\begin{array}{l}\text { The most satisfying for me is trying to understand the content material } \\
\text { as thoroughly as possible }\end{array}$ & .292 & .500 & .558 & .285 \\
\hline
\end{tabular}

Comprehensively, the students have positive perceptions and motivation towards the CPBL approach. This also reflects their strategies for learning where they give less concern towards the intrinsic goals, and strive for the extrinsic goals to be successful in their learning. Conceivably, the students already achieved good grades in their English language subject before that they have positive views in increasing their self-efficacy. The correlation between factors could provide more understanding towards the outcome of CPBL implementation in the writing classroom. Based on the results, the way students learn and their motivation need to be revamped. CPBL, as a new introduced approach in the language classroom may put the students out of their comfort zone and perhaps change their mind set about learning for information and knowledge. For instance, a study conducted by Yusof, Syed Hassan, Jamaludin and Harun (2011b) shows that CPBL has affected the students, where they did not put grade as their priority anymore. The students tend to see the knowledge as important and go for life-long learning. Therefore, it can be said that CPBL approach managed to give positive impressions on its implementation to the students.

\section{Conclusions}

Young graduates are facing more challenges in the competitive economy to secure a position in the employment sector. In accordance with the growing economy and technology, education too needs to be reviewed so that graduates are prepared of the upcoming challenges. A more practical approach to teaching and learning is needed to be aligned with the economy's demand. CPBL, a constructive and active approach could help students to enhance their skills; leadership, critical thinking, problem solving, social and creative thinking skills. Language classroom utilizes skills that makes CPBL relevant to be executed for its learning. Upon implementing the CPBL approach in the language classroom, a survey on the students' perceptions, motivation and strategies for learning has shown that students have positive perceptions towards its implementation in the language classroom. The most loaded factor is self-efficacy for learning, followed by extrinsic goal orientation and intrinsic goal orientation. All these factors correlate with one another that the students focus on their extrinsic goals more than their intrinsic goals to increase their self-efficacy. Hence, the introduction and the implementation of CPBL approach in the language classroom may present interesting results that could contribute to the existing literature of related field. 
INTERNATIONAL JOURNAL OF ACADEMIC RESEARCH IN BUSINESS AND SOCIAL SCIENCES

Vol. 9, No. 13, Special Issue: Revolutionizing Education: Challenges, Innovation, Collaboration, 2019, E-ISSN: 2222-6990 @ 2019 HRMARS

\section{References}

ACTE Career Readiness Series. (2010). Retrieved March 13, 2018, from https://www.acteonline.org/acte-career-readiness-series/

Adi, M. F., Phang, F. A., \& Yusof, K. M. (2012). Student Perceptions Change in a Chemical Engineering Class using Cooperative Problem Based Learning (CPBL). Procedia - Social and Behavioral Sciences, 56(Cl), 627-635. doi:http://dx.doi.org/10.1016/j.sbspro.2012.09.697

Azman, N. \& Ling, K. S. (2012). Problem-based learning in English for a second language classroom: Students' perspectives. The international Journal of Learning, 18(6), 109-126.

Battaglia, S. (2017). Importance of essay writing in university learning. Education.seattlepi.com. Retrieved September 9, 2017, from http://education.seattlepi.com/importance-essay-writinguniversity-learning-1401.html.

Chaudhary, A. K. \& Israel, G. D. (2017). The Savvy Survey \#8: Pilot Testing and Pretesting Questionnaires. UF/IFAS Extension, University of Florida. Retrieved October 12, 2018, from http://edis.ifas.ufl.edu

Costello, A. B., \& Osborne, J. W. (2005). Best practice in exploratory factor analysis: Four recomendations for getting the most from your analysis. Practical

Assesment Research and Evaluation, 10(7).

Dass, R. (2014). Literature and the 21st century learner. Procedia-Social and Behavioral Sciences, 123, 289-298.

Davidson, N., \& Major, C. H. (2014). Boundary crossings: Cooperative learning, collaborative learning, and problem-based learning. Journal on Excellence in College Teaching, 25(3\&4), 7-55.

Defazio, J., Jones, J., Tennant, F., \& Hook, S. A. (2012). Academic literacy: The importance and impact of writing across the curriculum-a case study. Journal of the Scholarship of Teaching and Learning, 10(2), 34-47.

ET (2018). O. D. C. 21st Century Learning: Research, Innovation and Policy. Retrieved June 12, 2018, from http://www.oecd.org/site/educeri21st/40554299.pdf.

Kek, M. Y. C. A., \& Huijser, H. (2011). The power of problem-based learning in developing critical thinking skills: preparing students for tomorrow's digital futures in today's classrooms. Higher Education Research \& Development, 30(3), 329-341.

Kumar, R., \& Refaei, B. (2017). Problem-Based Learning Pedagogy Fosters Students' Critical Thinking About Writing. Interdisciplinary Journal of Problem-Based Learning, 11(2), 1.

Kwok, M. (2003). Towards an understanding of employability skills development among university graduates for workplace entry. online at http://umanitoba.

ca/education/symposium03/documents/kwok03. pdf.

Long, C., Ming, Z., \& Chen, L. (2013). The study of student motivation on English learning in Junior middle school--A case study of No. 5 middle school in Gejiu. English Language Teaching, 6(9), 136.

Murugesan, V. (2003). Malaysia promotes excellence in English. ESL magazine, 6(2), 26-28.

Nausheen, M. (2016). An adaptation of the motivated strategies for learning questionnaire (MSLQ) for postgraduate students in Pakistan: Results of an exploratory analysis. Bulletin of Education and Research, 38(1), 1-16.

Parmjit S., Puzziawati, A. G., \& Teoh, S. H. (2009). Quantitative data analysis for novice researchers. Setapak, Kuala Lumpur: Primera Publishing. 
Scarino, A., \& Liddicoat, A. J. (2009). Teaching and learning languages: A guide. Carlton South, Australia: Curriculum Corporation.

Schmuk, P., Kasser, T., \& Ryan, R. M. (2000). Intrinsic and extrinsic goals: their structure and relationship to well-being in German and US college students. Social Indicators Research. Netherlands: Kluwer Academic Publishers.

Stan, E. (2012). The role of grades in motivating students to learn. Procedia-Social and Behavioral Sciences, 69, 1998-2003.

Suharta \& Luthan, P. L. A. (2013). Application of cooperative problem-based learning model to develop creativity and foster democracy, and improve student learning outcomes in chemistry in high school. Journal of Education and Practice, 4(25), 55-60.

Tabachnick, B. G., \& Fidell, L. S. (2007). Using multivariate statistics (5th ed.). Boston: Pearson/Allyn \& Bacon.

Wang, H. T., Chang, W., \& Lai, Y. F. (2012). A study On The Relationship Between Thinking Styles (Attitudes) and Collaboration Attitudes of College Students In Taiwan. Journal of Educational And Instructional Studies In The World, 46.

Yew, E. H., \& Goh, K. (2016). Problem-based learning: an overview of its process and impact on learning. Health Professions Education, 2(2), 75-79.

Yusof, K. M., Hassan, S. A. H., Jamaludin, M. Z., \& Harun, N. F. (2011a). Cooperative problem-based learning (CPBL): A practical PBL Model for engineering courses. International Journal of Emerging Technologies in Learning, 6(3), 12-20.

Yusof. K. M., Hassan, S. A. H., Jamaludin, M. Z., \& Harun, N. F. (2011b). Motivation and engagement of learning in the cooperative problem-based learning (CPBL) framework. ASEE Annual Conference and Exposition, $(\mathrm{Cl})$.

Yusof, K. M., Hassan, S. A. H., Jamaludin, M. Z., \& Harun, N. F. (2012). Cooperative problem-based learning (CPBL): Framework for integrating cooperative learning and problem-based learning. Procedia - Social and Behavioral Sciences, 56(Ictlhe), 223-232. doi:10.1016/j.sbspro.2012.09.649 